\title{
The Contribution of Vocational Competence Learning to the Creativity in Apparel Making among Vocational School Students
}

\author{
Sitti Aisyah \\ Home Economics Department \\ Universitas Negeri Makassar \\ Makassar, Indonesia \\ st.aisyah@unm.ac.id
}

\author{
Djoko Kustono, Syamsul Hadi \\ Mechanical Engineering Department \\ Universitas Negeri Malang \\ Malang, Indonesia
}

\begin{abstract}
Creativity is very fundamental in apparel making and can be developed through appropriate learning processes. The question that needs to be addressed is how to develop students' creative potentials through learning processes, especially in the vocational school for fashion design. This study aims to investigate: 1) the outcome of vocational competence learning among vocational school students; 2) the level of creativity in apparel making among vocational school students; 3) the contribution of vocational competence learning to the creativity in apparel making among vocational school students. The sample in this study was 55 students from two vocational schools of fashion design in Makassar, South Sulawesi. Descriptive data indicated that the learning outcome of vocational competence among vocational school students was satisfactory. The level of students' creativity in apparel making apparel was classified as moderately high. From inferential statistical analysis it was concluded that the vocational competence learning contributed significantly to the creativity of apparel making. The results of this study confirm that the learning activities performed at vocational school can improve students' creativity, which aims to support the competence formation and adaptability development for working the industrial sector.
\end{abstract}

Keywords - vocational competence learning, creativity in apparel making

\section{INTRODUCTION}

Fashion or clothing industry is one of the fourteen subsectors of national creative industries which focuses on the creation of goods and services by relying on the expertise, aptitude and creativity as intellectual properties. This creative industry can be a hope for the economy of Indonesia to rise, compete, and achieve excellence in the global economy. Fashion design is a creative activity associated with clothing, footwear, and other fashion accessories design. Besides, fashion design is also associated with the production of stylish apparels and accessories, as well as consultancy and distribution of fashion products [1].

According to Ciarniene [2], fashion industry is a highly globalized industry, where a garment is designed in one country, produced in another, and then worn by people in a third country. Clothing is a short-lived, highly volatile, and hard-to-predict designated style, thus clothing is only designed for a single period or season, measured in months or weeks. The demand for a fashion product is rarely stable or linear, which is likely to be influenced by seasons, movies or idols/actors. Therefore, it requires a high level of creativity and innovation in making a clothing.

The fashion industry by its very nature is ephemeral; it is fast-paced and subject to change over very short periods of time. Nothing in fashion is totally new; it is a cycle with reinvention at its core. The ability to innovate and create the 'new' is developed through strong research application, which is, therefore, an essential skill for a designer. Designers cannot create within a vacuum; they are like sponges, constantly absorbing the environment around them to find the inspiration needed to create a point of different 'newness'. Whether engaging with technological advances in fabric or reacting to a current political mood, designers are at the forefront of creative endeavors [3].

Fashion design education is currently facing major challenges in the rapidly expanding industry. Hence, the education sector must reconsider the future of the fashion industry. A great expectation is put on the future designers who will influence the development of fashion. Fashion design studies should be aimed at: (1) how fashion design education can be professionally imparted; (2) how fashion design education can be professionally developed, and (3) how fashion industry can contribute to the education sector. As a result, fashion design education seeks to overcome these challenges by placing greater emphasis on "rationale design" and conceptual processes to produce designers who understand the broader context in creating innovative new products and rethink the business systems in fashion industry [4].

Based on the decision of the Directorate General of Primary and Secondary Education Number $251 / \mathrm{C} / \mathrm{Kep} / \mathrm{MM} / 2008$ dated on 22 August 2008 the spectrum of vocational secondary education expertise consists of six areas of studies. One such skill program is Fashion Design. Fashion Design Expertise Program has a wide range of training and subjects. The training curriculum consists of basic vocational competencies (C2) studied in grade 10 and advanced vocational competencies (C3) studied in grade 11 and 12. Subjects of vocational competencies include Fashion Design, Pattern Making, Industrial Apparel Making, Custom-Made Clothing, and Ornament Making.

The carefully-constructed combination of theoretical and practical learning is intended to produce graduates, with certain level of quality, who are ready to enter the workforce. The success of vocational education is not only measured by 
quality alone, but also by its relevance. The quality of vocational education graduates (SMK) will be considered relevant by the employers of the graduates if what they acquire equally meet or is greater than their expectation [5].

Some subjects of vocational competencies are believed to be able to contribute significantly to the students' creativity through learning processes. Djamarah and Zain [6] asserted that every teaching and learning process always generates learning outcome. The remaining question is to what extent the learning outcome is achieved. This illustrates that what can be the focus of educators is how to manage learning processes to achieve the desired level of learning outcomes.

\section{METHOD}

\section{A. Study Design}

This study is a quantitative survey research. According to the basic concepts of variable correlations the design of this study is correlational research. It describes the relationship between independent and dependent variable. The independent variable included vocational competence learning and the dependent variable was students' creativity.

\section{B. Population and Sample}

The population in the study was the 12th grade students at SMK 6 and SMK 8 Makassar. The total number of 12th grade students of SMK 6 and SMK 8 year 2017 was 55. Thus, the population became the sample in this study because the population was less than 100 people.

\section{Data Collection Technique}

To measure the outcome of vocational competence learning, a set of documentation was used to collect the scores of the following subjects: Fashion Design, Pattern Making, Industrial Apparel Making, Custom Made Clothing and Ornament making. Observation sheet was used to gather the data about students' creativity by handing a structured written statement to the productive subject teachers in both vocational schools.

\section{Data Analysis Technique}

Data obtained from the study was analyzed using descriptive and inferential statistical analysis. Descriptive statistical analysis was performed by describing data from all variables in the following forms: frequency distribution, histogram, mode, median, mean value and standard deviation. Inferential statistical analysis was performed to test the proposed hypothesis. Inferential statistical analysis used in this study was simple regression analysis.

The formula for the simple linear Regression Equation Model is:

$$
\mathrm{Y}=\mathrm{a}+\mathrm{bY}
$$

Where :

$\mathrm{Y}=$ Response or Outcome Variable (Dependent)

$\mathrm{X}=$ Predictor or Explanatory Variable (Independent)

$\mathrm{a}=$ constant

$\mathrm{b}=$ regression coefficient (slope); Response generated by Predictor.

The values of $a$ and $b$ can be calculated using the following formula:

$$
a=\frac{(\Sigma y)(\Sigma x)-(\Sigma x)(\Sigma x y)}{n\left(\Sigma x^{2}\right)-(\Sigma x)^{2}}
$$

\section{RESULTS AND DISCUSSION}

\section{A. Descriptive Statistical Analysis}

This study was conducted in SMK Negeri 6 and SMK Negeri 8 Makassar with 55 students. Statistical descriptive analysis was completed using SPSS 16.0 for Windows. The mean, maximum, and minimum values were obtained, as well as the standard deviation. The data in Table I shows that the mean value of student's creativity is 3.2496 with standard deviation of .20229, while the mean value of vocational competence learning is 3.2243 with standard deviation of .13918 , and the sample number is 55 .

The data in Table II shows that the mean value of the students' score on vocational competence is 3.22 with maximum value of 3.57 and minimum value of 3 , hence the value range is .57 . The ability of vocational competence learning is moderately high.

As illustrated in Table III, the mean value of the level of creativity in apparel making among vocational school students is 3.24 , with maximum value of 3.62 and minimum value of 2.80 ; thus the range is .82 . This leads to the conclusion that the level of creativity in apparel making among vocational school students can also be categorized as moderately high.

Tabulation description of each study data group is presented in the following tables:

TABLE I. TABLE TyPE STYLES

\begin{tabular}{|l|l|l|l|}
\hline \multicolumn{2}{|c|}{} & N \\
\hline Students' Creativity & 3.24 & 0.20229 & 55 \\
\hline $\begin{array}{l}\text { Vocational } \\
\text { Competence Learning }\end{array}$ & 3.2243 & 0.13918 & 55 \\
\hline
\end{tabular}

TABLE II. DESCRIPTION OF VOCATIONAL COMPETENCE LEARNING

\begin{tabular}{|l|c|}
\hline & $\mathbf{3 . 2 2 3}$ \\
\hline Median & 3.2000 \\
\hline Standard Deviation & .13918 \\
\hline Sample Variance & .019 \\
\hline Kurtosis & -.246 \\
\hline Skewness & .464 \\
\hline Range & .57 \\
\hline Minimum & 3 \\
\hline Maximum & 3.57 \\
\hline
\end{tabular}

\section{B. Statistical Analysis}

\section{1) Normality Testing}

The normality test was performed to determine whether the sample data was from a normally distributed population or not. The results of normality testing on the ability of vocational competence learning and creativity in apparel making are shown in the table below.

Based on the data in Table 4, for vocational competence learning, the $p$ value is $0.116(\alpha=0.05)$. Data is normally distributed if $\mathrm{p}$ value $>\alpha$. Therefore, it can be concluded from the data that the ability of vocational competence learning is in normal category. 
The $\mathrm{p}$ value for the creativity in apparel making is 0.055 . Data is normally distributed if $\mathrm{p}$ value $>\alpha$. Therefore, it can be concluded from the data that the creativity in apparel making is in normal category.

\section{2) Linearity Testing}

Linearity test is required to determine whether the relationship between independent and dependent variable is linear or not. The distribution is linear if $p<0.05$. The results of linearity testing on the data of vocational competence learning and creativity in apparel making are summarized in the table below.

Based on data in Table V, the correlation coefficient for vocational competence learning and creativity in apparel making among vocational school students is 0.569 ; from the output it can be observed that the significant value is 0.000 . To test the significance of the correlation coefficient, the acquired significance value should be compared with $\alpha=0.05$. Because $p=0.000$ is less than $\alpha=0.05$, H0 is not accepted. It can be concluded that the correlation coefficient between vocational competence learning and creativity in apparel making is statistically significant.

TABLE III. RESULTS OF NORMALITY ANALISIS

\begin{tabular}{|l|l|l|l|}
\hline \multirow{2}{*}{} & \multicolumn{3}{|c|}{ Shapiro-Wilk } \\
\cline { 2 - 4 } & \multicolumn{1}{|c|}{ Statistic } & \multicolumn{1}{c|}{ df } & \multicolumn{1}{c|}{ Sig. } \\
\hline $\begin{array}{l}\text { Vocational Competence } \\
\text { Learning }\end{array}$ & .966 & 55 & .116 \\
\hline Students' Creativity & .958 & 55 & .055 \\
\hline
\end{tabular}

TABLE IV. RESULTS OF LINEARITY ANALYSIS

\begin{tabular}{|l|l|l|l|}
\hline \multicolumn{2}{|c}{ Correlations } & \multicolumn{1}{|c|}{$\begin{array}{c}\text { Students' } \\
\text { Creativity }\end{array}$} & $\begin{array}{l}\text { Vocational } \\
\text { Competenc } \\
\text { e Learning }\end{array}$ \\
\hline $\begin{array}{l}\text { Pearson } \\
\text { Correlation }\end{array}$ & Students' Creativity & 1.000 & .569 \\
\cline { 2 - 4 } & $\begin{array}{l}\text { Vocational Competence } \\
\text { Learning }\end{array}$ & .569 & 1.000 \\
\hline \multirow{2}{*}{ Sig. (1-tailed) } & Students' Creativity &. & .000 \\
\cline { 2 - 4 } & $\begin{array}{l}\text { Vocational Competence } \\
\text { Learning }\end{array}$ & .000 &. \\
\hline \multirow{2}{*}{$\mathrm{N}$} & Students' Creativity & 55 & 55 \\
\cline { 2 - 4 } & $\begin{array}{l}\text { Vocational Competence } \\
\text { Learning }\end{array}$ & 55 & 55 \\
\hline
\end{tabular}

\section{Hypothesis Testing Results}

\section{1) Coefficient of Determination Analysis}

Coefficient of determination test was performed to determine the degree of linear relationship between correlation coefficients of variable rx,y. The results of the coefficient of determination test can be seen in in table 6 .

The data in Table VII shows that the coefficient of determination between variable rx,y is 0.32 or $32 \%$. This signifies that the relationship between these two variables is quite significant or $32 \%$ of creativity in apparel making is influenced by vocational competence learning while the other $68 \%$ is influenced by other factors not investigated in this study.

\section{2) Hypothesis testing}

The influence of variable $\mathrm{X}$ (vocational competence learning) towards variable $\mathrm{Y}$ (creativity in apparel making) is illustrated in Table VII.

The result of ANOVA test using F-test is 25,438 with significance level of 0.000 . By comparing the $\mathrm{F}$ count and $\mathrm{F}$ table, it can be inferred that Ho is rejected, thus the correlation coefficient is statistically significant. Thus, the proposed hypothesis of vocational competence learning may affect creativity in apparel making among vocational school students is accepted.

TABLE V. COEFFICIENT OF DETERMINATION TEST

\begin{tabular}{|c|c|c|c|c|c|c|c|c|c|}
\hline \multirow[b]{2}{*}{ Model } & \multirow[b]{2}{*}{$\mathbf{R}$} & \multirow[b]{2}{*}{$\begin{array}{c}\text { R } \\
\text { Squa } \\
\text { re }\end{array}$} & \multirow[b]{2}{*}{$\begin{array}{c}\text { Adju } \\
\text { sted } \\
\text { R } \\
\text { Squa } \\
\text { re }\end{array}$} & \multirow{2}{*}{$\begin{array}{l}\text { Std. } \\
\text { Error } \\
\text { of the } \\
\text { Estim } \\
\text { ate }\end{array}$} & \multicolumn{5}{|c|}{ Change Statistics } \\
\hline & & & & & $\begin{array}{c}R \\
\text { Square } \\
\text { Chang } \\
e\end{array}$ & $\begin{array}{c}\text { F } \\
\text { Cha } \\
\text { nge } \\
\end{array}$ & $d f 1$ & $d f 2$ & $\begin{array}{c}\text { Sig. } F \\
\text { Change }\end{array}$ \\
\hline 1 & $69^{\mathrm{a}}$ & .324 & .312 & .16785 & .324 & $\begin{array}{l}25.4 \\
38\end{array}$ & 1 & 53 & .000 \\
\hline
\end{tabular}

TABLE VI. - TEST

\begin{tabular}{|l|l|l|l|l|l|l|}
\hline \multicolumn{2}{|c|}{ Model } & \multicolumn{1}{c|}{$\begin{array}{c}\text { Sum of } \\
\text { Squares }\end{array}$} & Df & $\begin{array}{c}\text { Mean } \\
\text { Square }\end{array}$ & F & Sig. \\
\hline \multirow{3}{*}{1} & Regression & .717 & 1 & .717 & 25.438 & $.000^{\mathrm{a}}$ \\
\cline { 2 - 7 } & Residual & 1.493 & 53 & .028 & & \\
\cline { 2 - 7 } & Total & 2.210 & 54 & & & \\
\hline
\end{tabular}

REGRESSION EQUATIONS

\begin{tabular}{|c|c|c|c|c|c|c|}
\hline & \multirow[b]{2}{*}{ Model } & \multicolumn{2}{|c|}{$\begin{array}{c}\text { Unstandardized } \\
\text { Coefficients }\end{array}$} & \multirow{2}{*}{\begin{tabular}{|c|}
$\begin{array}{c}\text { Standard } \\
\text { ized } \\
\text { Coefficie } \\
\text { nts }\end{array}$ \\
Beta \\
\end{tabular}} & \multirow[b]{2}{*}{$\mathbf{T}$} & \multirow[b]{2}{*}{ Sig } \\
\hline & & B & $\begin{array}{c}\text { Std. } \\
\text { Error }\end{array}$ & & & \\
\hline \multirow[t]{2}{*}{1} & (Constant) & .581 & .530 & & 1.097 & .278 \\
\hline & $\begin{array}{l}\text { Vocational } \\
\text { Competence } \\
\text { Learning }\end{array}$ & .828 & .164 & .569 & 5.044 & .000 \\
\hline
\end{tabular}

The regression equation is:

Error! Reference source not found.

Error! Reference source not found.

\section{Interpretation of numbers}

- Constants of .828: if the vocational competence learning $(\mathrm{x})$ value is 0 then the value of the creativity in apparel making $(\mathrm{Y})$ is negative .581

- Variable regression coefficient value $(x)$ of .828: if the value of vocational competence learning is 1 , the value of the creativity in apparel making (Y) will have an increase by .828 . The positive coefficient value was translated as a positive relationship between vocational competence learning and creativity in apparel making among vocational school students. The higher the value of vocational competence learning, the higher the level of creativity of vocational students. 
This study formulated three problems: 1) what outcome resulted from vocational competence learning among vocational school students; 2) to what extent the level of creativity in apparel making among vocational school students is; 3) how much vocational competence learning contributes to the creativity in apparel making among vocational school students.

The result of descriptive analysis suggests that the outcome of vocational competence learning among vocational school students was in normal category. The mean value was 3.22 , the maximum value was 3.57 and the minimum value was 3 . The result of this study explains how vocational competence learning reflects the learning processes that students have to undertake to achieve the predetermined learning objectives. The quality of learning is strongly determined by the capability of educational units in directing the learning processes. This is supported by the theory from Supaman [7], who contended that learning process was built on specific learning strategies (instructional strategy). Such strategies were the manifestation of synthesis and learning activities phases, methods, media and tools, as well as the time and they are entirely organized to present the learning content (instructional contents) according to the predetermined learning objectives.

The result of descriptive analysis suggests that the creativity in apparel making among vocational school students was in normal category, with mean value of 3.24 , maximum value of 3.62 and minimum value of 2.80 . The result of this study demonstrates that the creativity of vocational school students in the fashion design program is quite significant as the students who produce innovative fashion products. Due to the high level of creativity possessed by these vocational school students, they are expected to have the ability to develop themselves, particularly in the development of the business side of fashion, by using ideas in creating new creations. Lee and Charlotte Jirousek [8] asserted that designing fashion products relating to apparel making is about how to generate ideas from the inspiration, lifestyle or even personal feelings of the designer. From creative works, one may derive satisfaction both for oneself and others who use them. Thus, creativity is vital in the process of apparel making since the competition of this field is very fierce.

The inferential analysis resulted in the coefficient of determination between variables rx, y of 0.32 or $32 \%$ suggesting that $32 \%$ of the creativity in apparel making was influenced by vocational competence learning, while the other $68 \%$ was influenced by other factors not investigated in this study. The result of ANOVA test using $F$ test was 25,438 with significance level of 0.000 . By comparing the $\mathrm{F}$ count and $\mathrm{F}$ table, it can be concluded that $\mathrm{H} 0$ was rejected and the correlation coefficient was statistically significant. Thus, the proposed hypothesis of vocational competence learning may affect creativity in apparel making among vocational school students is accepted. The regression coefficient of variable (x) was 1.068. This implies that if the ability to learn vocational competency is 1 then the creativity in apparel making (Y) will have an increase by .828. Positive coefficient value translates as a positive relationship between vocational competence learning and creativity in apparel making among vocational school student. The higher the value of vocational competence learning, the better the creativity of vocational school students.

The results of this study may help explain how developing students' creativity can normally be achieved by using various ways or methods during the learning processes in school. This may include acclimatizing a situation that may prompt students' ability to work. Creativity is indispensable for fashion design students where high level of creativity may help them produce fashion goods of exceptional quality.

The results of this study are also in line with Ostrower in Sotoriva, et al., [9] who argued that creative ideas are woven more easily by individuals who have good preparation and sufficient knowledge about particular subject. Furthermore, Reid \& Petocz [10] explained that the educational principles that buttress creative learning are those where the students are supported as they formulate the problems that need to be solved and that the students should be given enough autonomy to reach a conclusion (or product) that enables them to make interesting and innovative connection. Kurjono [11] found that the teachers' competencies, assessed pedagogically and professionally, had a significant and positive direct influence on the students' creative attitude. Hence, creative teaching can be summed up as consisting of an arrangement of learning environment that encourages students to see the essence and detail of the subject, formulate and solve problems, as well as recognize the interrelationships between the various fields, which they may take ideas from and generate a new one in their work.

Based on the result of this study, the role of partnership between vocational schools and industries as a place to have an internship or training for students have to be improved in order to prepare graduates entering the field of fashion design professionally. This role is really significant because the dynamic competition in fashion industries may require the future professionals to have a complex knowledge that will allow them to anticipate the fast and unpredictable changes in fashion styles.

\section{CONCLUSION}

Vocational competence learning among vocational school students was assessed from the summary of the learning outcome of fashion design, pattern making, industrial apparel making, custom made clothing and ornament making classes, was categorized as satisfactory. Based on the descriptive results, the mean value of students (3.22) was categorized as satisfactory. According to the descriptive results, the mean value of the students was 3,24 , the maximum value was 3,64 , and the minimum value was 2.80 .

Students' creativity in apparel making was satisfactory. The mean value was 3.24, the maximum value was 3.62 and the minimum value was 2.80 .

There was a significant influence of the outcome of vocational competence learning on the creativity in apparel making. The significance between variables $\mathrm{X}$ and $\mathrm{Y}$ was 0,32 or $32 \%$ which can be translated as a substantial relationship. It can also be interpreted as $32 \%$ of the creativity in apparel making influenced by vocational competence learning, while the other $68 \%$ is influenced by other factors not investigated in this study. 


\section{REFERENCES}

[1] M. o. T. o. RI, "Pengembangan Ekonomi Kreatif Indonesia 2025," Study of Creative Industries, , Indonesia, 2008.

[2] R. M. V. Ciarnienea, "Agility and Responsiveness Managing Fashion Supply Chain," in Procedia - Social and Behavioral Sciences, 150: $1012-1019,2014$.

[3] E. Mbonu, "Fashion Design Research," Laurence King Publishing Ltd, London, 2014.

[4] S. Faerm, "Towards a Future Pedagogy: The Evolution of Fashion Design Education," International Journal of Humanities and Social Science, vol. 2, p. 23, 2012.

[5] D. Perguruan, "Model Implementasi Praktik Kerja Industri Siswa SMK Program Keahlian Teknik Bangunan Di Jawa Tengah Dan D.I. Yogyakarta," in Artikel Ilmiah Penelitian Unggulan, Indonesia, 2014.
[6] S. B. A. Z. Djamara, Strategi Belajar Mengajar, Jakarta: Rineka Cipta, 2013.

[7] A. Suparman, Desain Instruksional Modern, Indonesia: Erlangga, 2012.

[8] J. S. \&. C. J. C. o. H. Leea, "The Development of Design Ideas in the Early Apparel Design Process: A Pilot Study.," International Journal of Fashion Design, Technology and Education. Department of Fiber Science and Apparel Design, 2015.

[9] M. e. a. Sotoriva, A New Language for Creativity In Fashion Design., Milano: Università Cattolica Del Sacro Cuore Sotoriva., 2012.

[10] J. G. Gomez, "What Do We Know About Creativity?," The Journal of Effective Teaching, pp. 31-43, 20017.

[11] Kurjono, "Pengaruh Faktor Siswa, Kompetensi Guru Danlingkungan Keluarga, Terhadap Sikap Kreatif Dan Sikap Inovatif Dan Implikasinya Terhadap Motivasi Kewirausahaan," Jurnal Manajerial, pp. 22-31, 2011. 